\section{LABYRINTHODONTS}

\section{Amphibians of the Coal}

Vertebrate Palaeontology Correspondent

THE large and varied amphibians known as labyrinthodonts were the first colonists of the land. They include some six or seven groups which differ principally in their vertebral structure. One group, characterized by having two disklike centra in each vertebra, is commonly known as the Embolomeri. In a comprehensive and well illustrated review of this group (Encyclopedia of Paleoherpetology, Part 5A; Stuttgart, Fischer) A. L. Panchen has preferred to revive the original name Anthracosauria - a term which refers to the coal deposits in which most members have been found.

The long snout, the elongate body with (at least in the best known form, Archeria) a long tail bearing a dorsal fin and the relatively small limbs, all suggest that these amphibians were aquatic predators which swam by lateral undulations of both the body and tail aided by paddling with the hind limbs, which may have been webbed. Such a mode of life is supported by their preservation in coal deposits. Panchen points out that they are never found in humic coals, but usually in sapropelic coals, laid down in the deep anaerobic mud which formed in stagnant conditions. The varied fish fauna of these coals includes xenacanth sharks; Panchen notes that these are unlikely to have had methods of aerial respiration, and infers that the environment was a large lake, with oxygenated surface waters but stagnant depths, and with no seasonal overturn of the water.

Anthracosaurs are known from the United States, Great Britain and Bohemia-all, in pre-drift times, in western Laurasia-and Panchen shows that all the localities were close to their contemporary equator. The earliest (Lower Carboniferous) forms all came from the eastern United States or Great Britain; since the earliest known amphibians, the ichthyostegids, were found in Greenland (in those days, adjacent to Western Europe), Panchen speculates that this may in fact have been the area in which tetrapods evolved.

The generally accepted theory of relationship between the labyrinthodont amphibian groups is that of Romer, who believes that the double disk condition of the vertebrae of anthracosaurs evolved from a condition similar to that known as rhachitomous, in which neither part of the centrum forms a complete disk. This view implied that early anthracosaurs would have had rhachitomous vertebrae, and this prediction seemed to be substantiated by Pholidogaster. This early Mississippian (Lower Carboniferous) labyrinthodont from Scotland was based on a skeleton which proved to have rhachitomous vertebrae. Though the skull of this specimen was obscured by a hard ironstone matrix, another skull (the horizon and locality of which were unknown) had earlier been attributed to Pholidogaster, and was of anthracosaur pattern. Panchen, however, is convinced that the two specimens are not related, that their matrices are different, indicating that they did not come from the same horizon, and that the ornament on the skull of the original specimen of Pholidogaster (which has now been partially cleaned) is unlike that of any anthracosaur. He suggests that the more solid type of vertebral centrum, found both in the anthracosaurs and in their relatives the seymouriamorphs, was the original condition for these two groups. $\mathrm{He}$ believes that it evolved primarily as an adaptation for terrestrial locomotion and only later proved also adaptable to the environment and locomotion of the elongate anthracosaurs.

Panchen's suggestion seems to be supported by Mauchchunkia, an early Mississippian anthracosaur from Greer, West Virginia, described by Hotton (Kirtlandia, No. 12, 1; 1970) in which the body is short and the limbs are stout. Two other amphibians from Greer have been described by Romer (Kirtlandia, Nos. 6, 1969; and 10, 1970); one is an anthracosaur, the other is an ancestor to a peculiar group of Upper Carboniferous labyrinthodonts known as colosteids. It is clear that this fauna is likely to reveal new and unexpected aspects of very early amphibian evolution, and further descriptions will be eagerly awaited.

\section{BIOTELEMETRY}

\section{Tracking of Wildlife}

from a South African Correspondent WIDESPREAD interest in biotelemetry has existed in South Africa only for the past five years or so. The good attendance at the symposium on biotelemetry, arranged by the Council for Scientific and Industrial Research (CSIR) at the University of Pretoria (November 29-December 2), suggests, however, that this field is now firmly established.

In a keynote address on sensing and transmitting biological information from animals and man, Professor R. Stuart Mackay (University of Boston) delighted the biologists by making it all sound terribly easy. The other extreme was represented by Professor John R. Tester (University of Minnesota), who described the complex tracking system used by him, which involves continuous tracking of up to fifty-two animals at a time by two continually rotating antennae. Signals are fed into a

\title{
Pokeweed Mitogen and Immunoglobulin Synthesis
}

POKEWEED mitogen is one of the plant lectins which, like the better known phytohaemagglutinin (PHA), can be used to stimulate lymphocytes in vitro. In the early days of work of this kind, particularly in relation to PHA, there was much argument as to whether the lymphocyte stimulation led to antibody production and was thus equivalent to an immune response. As so often in cellular immunology there were two contrasting opinions and the dialogue was fierce. Now the waters are calmer, at least with PHA, and there is general agreement that activation of lymphocytes with this material leads to protein synthesis but not to large scale production of immunoglobulins. In next Wednesday's Nature New Biology (January 5), Parkhouse, Janossy and Greaves claim that activation of $B$ with pokeweed mitogen leads to the production of immunoglobulins.

Parkhouse et al. incubated lymphocytes from either normal mice or from animals with a quantitative deficiency of $T$ cells with pokeweed mitogen or with PHA. After four days the cultures were incubated with radioactive leucine and the cultures were then harvested. The supernatants and cell pellets were treated separately in such a manner as to quantitate any radioactive immunoglobulins produced. It was found that cells stimulated with pokeweed mitogen had a greater percentage of protein synthesis devoted to the production of immunoglobulins than did the PHAstimulated cells. This selective stimulation of immunoglobulin synthesis also seemed to be more marked in the cells from $T$-cell deficient mice than in cells from normal animals. In other words, the effect of pokeweed mitogen in inducing immunoglobulin synthesis is likely to be on B cells rather than T cells. The immunoglobulins which were synthesized were almost entirely IgM and free light chains; no significant amounts of IgG were detected.

What kinds of IgM are synthesized by the $B$ cells in, for example, a myeloma? It is not thought that the IgM produced is an anti-pokeweed mitogen antibody though no tests of this unlikely possibility seem to have been made. Parkhouse et al. prefer to think that the response they describe is essentially "aspecific" and that the immunoglobulins secreted will prove to be heterogeneous, or polyclonal in the accepted jargon. If they are wrong the clonal selection hypothesis will take a heavy jolt. 